mgr Bożena Błażewicz-Tomczyk

Akademia Sztuk Pięknych im. Jana Matejki w Krakowie

\title{
PRZESTRZEŃ W CZASACH ZARAZY
}

\section{Artykul przeglądowy}

\section{Spis treści}

Abstrakt 51

Słowa klucze 51

Początek 52

Zakazany dotyk 53

$150 \mathrm{~cm}$ samotnego bezpieczeństwa 53

Wspomnienie 1. Split, 201954

Uroki pandemicznej kolacji 55

Kult bez wyznawców 56

Wspomnienie 2. Rzym, 201657

Muzyka w pustej filharmonii 57

Kamerką w intymność 58

Luxury room miejscem odosobnienia 59

Wspomnienie 3. Skyline webcams, kwiecień 202060

Wnioski 61

Bibliografia 63 
TOM 2 (2021), NR 1

\begin{abstract}
Abstrakt
Artykuł w sposób przeglądowy porusza temat zależności pomiędzy człowiekiem a przestrzenią w kontekście wprowadzonej w ubiegłym roku przymusowej izolacji. Odwołuje się do sposobów odczuwania przestrzeni scharakteryzowanych przez E.T. Halla oraz do rodzajów dystansu opisanych przez proksemikę. Opowiada o zaobserwowanych reakcjach ludzi na wymuszone zachowanie dystansu społecznego i próby wprowadzania zmian w sposobie użytkowania miejsc wspólnych. Zwraca uwagę na całkowitą zmianę funkcji przestrzeni, jaką było łączenie ludzi, na funkcję dzielącą współużytkowników.

Co pewien czas nastaje dzień, kiedy pielęgnowana przez nas pewność stałości istniejącego świata okazuje się całkowitą ułudą. W jednej chwili musimy zmienić sposób funkcjonowania i wszystkie nasze przyzwyczajenia, dostosowując się do nowej, niechcianej rzeczywistości. Za każdym razem zdziwieni niepomyślnym obrotem spraw wierzymy, że „,następnym razem” będziemy mądrzejsi dzięki przetrwaniu kolejnej porażki. „Na świecie było tyle dżum co wojen. Mimo to dżumy i wojny zastają ludzi zawsze tak samo zaskoczonych"'.
\end{abstract}

\title{
Słowa klucze
}

przestrzeń, współdzielenie, użytkowanie, łączenie, dzielenie, proksemika, odczuwanie, dystans, odosobnienie, pustka, zmiana znaczenia, zagubienie, miasto, wspólnota, zmysły, lęk, wyobcowanie, pandemia, lockdown, mikroprzestrzenie, bańki społeczne, izolatoria, miejsca kwarantanny, praca i edukacja online, bezpieczeństwo, samotność, kontakty społeczne, pandemia, COVID-19, izolacja, zamknięcie 
TOM 2 (2021), NR 1

\section{Początek}

Bakcyl dżumy nigdy nie umiera i nie znika [...], nadejdzie być może dzień, kiedy na nieszczęście ludzi i dla ich nauki dżuma obudzi swe szczury i pośle je, by umierały w szczęśliwym mieście².

Już rok mija od czasu, kiedy nasze życie zupełnie się odmieniło. Normalne dotychczas czynności i aktywności musiały zostać z dnia na dzień zawieszone aż do odwołania. Cały świat wokół nas, tak żmudnie przez lata tworzony z myślą o jak najlepszym i najpełniejszym wspólnym jego wykorzystaniu, zatrzymał się i zmierza w nieznanym kierunku.

Dotychczas wszelkie starania skupiały się na tym, aby projektowana przestrzeń jak najlepiej łączyła użytkujących ją ludzi. Teraz zażądano od nas czegoś zupełnie innego - musimy istniejącą wokół nas, znajomą i zaakceptowaną dla naszych działań przestrzeń podzielić tak, aby była w jak najmniejszym stopniu powodem do bliskich kontaktów z drugim człowiekiem.

„Miasta dla ludzi” - pod tym hasłem jeszcze nie tak dawno temu podpisywali się niemal wszyscy zainteresowani tworzeniem przestrzeni użytkowej. Miasto jako miejsce najlepiej oddające złożoność zależności pomiędzy człowiekiem a człowiekiem ${ }^{3}$ oraz człowiekiem a przestrzenią było polem doświadczalnym dla badań nad przestrzenią idealną pozwalającą ich szczęśliwym mieszkańcom na życie w pełni. Jan Gehl ${ }^{4}$ w swojej książce Miasta dla ludzi opisuje konieczność projektowania miast jak najlepiej spełniających funkcje społeczne. Według Gehla miasto powinno zachęcać do wspólnej aktywności w równowadze i harmonii. Ważne jest tworzenie parków, placów i innych publicznych przestrzeni skupiających mieszkańców i prowokujących do jak największej ilości aktywności ${ }^{5}$. Projektowana przestrzeń powinna jak najlepiej łączyć ludzi - taka myśl przyświecała projektantom i architektom przez ostatnie dziesięciolecia. Rok 2020 przyniósł ogromną zmianę - przestrzeń miejska, a w zasadzie każda przestrzeń współdzielona z innymi, stała się postrzegana jako element opresyjny. Przestrzenie miejskie z dnia na dzień opustoszały, wprowadzony całkowity lockdown ${ }^{6}$, a w najlepszym razie nakaz bezwzględnego przestrzegania dystansu społecznego, uniemożliwił dotychczasowy model korzystania z wspólnych miejsc.

$2 \quad$ Tamże.

3 W artykule Sztuka Projektowania (miejsc) przestrzeni międzykulturowych (w: Architektura na styku kultur. Nowa Przestrzeń, 2018) prof. Beata Gibała-Kapecka omawia funkcję przestrzeni publicznej jako miejsca tworzenia się relacji pomiędzy użytkownikami, miejsca komunikacji międzykulturowej oraz miejsca interakcji.

$4 \quad$ J. Gehl, Miasta dla ludzi, Kraków 2018.

$5 \quad$ O istocie ,łączenia ludzi” poprzez udział w przestrzeniach publicznych mogliśmy przeczytać w artykułach dr Katarzyny Stryszowskiej (Wielowymiarowość przestrzeni publicznych) oraz dr hab. Krystyny Paprzycy (Miejsce i wspólnota miejsca w strukturze miasta?) w ,,inAW Journal Multidisciplinary Academic Magazine” nie tak dawno, bo w 2020 roku.

$6 \quad$ Lockdown - wzbudzający negatywne konotacje termin oznaczający drastyczne obostrzenia mające na celu przeciwdziałanie pandemii, został ogłoszony przez autorów słownika Collinsa słowem roku 2020, a w Niemczech zyskał miano najpopularniejszego anglicyzmu roku 2020. 
TOM 2 (2021), NR 1

\section{Zakazany dotyk}

Proksemika ${ }^{7}$, która w ostatnim czasie zyskała miano coraz bardziej niezbędnej i obowiązkowej wiedzy dla każdego projektanta, nauczyła nas postrzegania zależności pomiędzy przestrzenią i człowiekiem jako sumy wielu zjawisk. Dzięki niej wiemy, jak postrzegana może być przestrzeń w zależności od przyjętego przez człowieka dystansu określonego uwarunkowaniami osobniczymi i kulturowymi. Wszystkie przestrzenie architektoniczne budowane i tworzone z myślą o ludziach za jeden z głównych celów obierały umiejętne łączenie i zbliżanie użytkowników. Miały możliwość łączenia uczestników przestrzeni poprzez ich wspólne bliskie przebywanie w jednej przestrzeni, poprzez umożliwianie im odbierania tych samych wrażeń dźwiękowych, węchowych, dotykowych i wzrokowych.

Przyjemnie jest nacisnąć klamkę wypolerowaną przez tysiące dłoni, które przeszły przez te drzwi przed nami; czysty blask zużycia o nieokreślonym wieku przeobraża się w obraz powitania i gościnności. Klamka jest uściskiem dłoni budynku. Zmysł dotyku łączy nas z czasem i tradycją: poprzez wrażenia dotykowe ściskamy dłonie niezliczonych pokoleń ${ }^{8}$.

Teraz oczekujemy od tych samych wnętrz czy przestrzeni, aby jak najlepiej, jak najtrwalej nas od siebie oddzielały. Słyszymy, że nie możemy czy też nie powinniśmy wchodzić w zbytnią interakcję z samym wnętrzem. Uświadamiani wciąż o czającym się na każdej powierzchni niebezpieczeństwie nie możemy w sposób naturalny zachwycać się fakturą czy zapachem materiałów budowlanych czy wykończeniowych. Bezwiedny, odruchowy dotyk gładkiej powierzchni wypolerowanej balustrady stał się marzeniem. Do rozpoznania przestrzeni pozostały nam wzrok i słuch, którymi póki co możemy posługiwać się w nieograniczony sposób.

\section{$150 \mathrm{~cm}$ samotnego bezpieczeństwa}

Edward T. Hall ${ }^{9}$ w swoich publikacjach dotyczących relacji przestrzennych opisał różne formy postrzegania przez człowieka przestrzeni poprzez zróżnicowany dystans. Najmniejszym z dystansów jest dystans intymny ${ }^{10}$, który osiąga maksymalnie $45 \mathrm{~cm}$. Na taką odległość dopuszczane są osoby najbliższe, taka odległość buduje bliskie relacje, podtrzymuje więź. Wzrok zostaje zastąpiony poprzez inne zmysły - słuch, dotyk i zapach.

Następnym w kolejności jest dystans indywidualny ${ }^{11}$, który zajmuje przestrzeń od 45 do $120 \mathrm{~cm}$. To jest strefa dla przyjaźni, więzi rodzinnych czy innych bliskich zależności. Taka odległość umożliwia

\footnotetext{
$7 \quad$ Proksemika - interdyscyplinarny kierunek badań dotyczący kulturowych, behawioralnych i socjologicznych aspektów relacji przestrzennych między ludźmi oraz między człowiekiem a otoczeniem materialnym - termin wprowadzony w latach 60. XX wieku przez E.T. Halla.

8 J. Pallasmaa, Oczy skóry, Kraków 2012.

9 E.T. Hall, Ukryty wymiar, Warszawa 1976.

10 Dystans intymny E.T. Hall dzieli dodatkowo na fazę bliższą, do $20 \mathrm{~cm}$, i dalszą, do $45 \mathrm{~cm}$.

11 Termin wprowadzony przez Heiniego Hedigera został opisany dokładniej przez E.T. Halla, według którego również podzielić go można na bliższy i dalszy.
} 
TOM 2 (2021), NR 1

kontakt dotykowy - pozostajemy „na wyciągnięcie ręki”. To przestrzeń komfortu do rozmów z bliskimi znajomymi, rośnie w niej rola wzroku, a powoli zmniejsza się możliwość posługiwania się innymi zmysłami - węchem, dotykiem, odczuwania ciepła drugiej osoby.

Trzeci w kolejności, dystans społeczny ${ }^{12}$, rozciąga się pomiędzy 120 a $360 \mathrm{~cm}$ wokół danej osoby. W tym obszarze poruszamy się pomiędzy ludźmi obcymi oraz dalszymi znajomymi. To dobry dystans do kontaktów oficjalnych, zawodowych. To tak zwany dystans niezobowiązujący - pozwala na rozpoczęcie lub zakończenie wymiany zdań w dowolnym momencie. W tej przestrzeni w kontaktach z drugą osobą posługujemy się przede wszystkim wzrokiem i słuchem. Jeśli nie jest możliwe zachowanie dystansu społecznego - na przykład w kasach w banku, urzędach - stosuje się przegrody wprowadzające psychologiczną barierę, powodujące odpowiednie zachowania.

Wymagany od roku dystans społeczny bezpieczny z punktu widzenia epidemiologów, określony na minimum 1,5 m, a najlepiej $2 \mathrm{~m}$, odstępu pomiędzy osobami znajdującymi się w przestrzeni publicznej wymusza poniekąd zachowania opisane powyżej. Jako „dystans niezobowiązujący” nie sprzyja nawiązaniu nowych czy utrzymaniu istniejących już więzi społecznych, uniemożliwia wspólne korzystanie z przestrzeni na zasadach im pierwotnie przypisanych.

\section{Wspomnienie 1. Split, 2019}

Upalne wieczory w Splicie najchętniej spędza się w perystylu pałacu Dioklecjana. Schody otaczające dziedziniec służą za kawiarniane stoliki, tłoczą się na nich zmęczeni całodziennym zwiedzaniem miasta turyści. Zmrok i ciepłe światła zamieniają przestrzeń placu w ogromny salon obrysowany rzędem kolumn z jednej strony i wklejonymi pomiędzy kolumnadę kamiennymi domami po drugiej stronie. Pośrodku mieszają się przechodzący tłumnie ramię w ramię obywatele świata oraz kelnerzy z pobliskich kawiarń i barów. Umiejętnie poruszają się po wypolerowanej przez stulecia kamiennej posadzce, z gracją na dużych tacach noszą schłodzone napoje i wręczają je tulącym się mimowolnie do siebie w tłoku szczęśliwym, obcym sobie ludziom. Ci bez zastanowienia opierają się o swoich sąsiadów, dzielą wspólnie stopnie oraz wrażenia, nucą za umilającymi czas ulicznymi muzykami, śmieją się głośno, rozmawiają. dystans publiczny, nazwany nie bez powodu dystansem formalnym. 


\section{Uroki pandemicznej kolacji}

Pojawiające się od czasu do czasu epizody „rozluźnienia obostrzeń pandemicznych” zezwoliły na chwilowe korzystanie z lokali gastronomicznych. Według wytycznych blaty stolików w restauracji powinny być ustawione w odstępie co najmniej $200 \mathrm{~cm}$ od siebie. Goście powinni wchodzić do pomieszczenia i siadać za stołem w maseczce, którą mogą ściągnąć na czas spożywania posiłku. Niemożliwe jest korzystanie ze stołów szwedzkich czy barów. Restauracja podzielona powinna być w sposób czytelny i jasny na strefy, które umożliwią odpowiednią odległość pomiędzy gośćmi nienależącymi do wspólnego gospodarstwa domowego. Powierzchnie wspólne wraz ze stolikami muszą być dezynfekowane co 15 minut.

W wielu lokalach zaczęto szybko szukać rozwiązań, które umożliwiłyby w miarę przyjazne dla człowieka korzystanie z miejsc, które kojarzone były dotychczas z przyjemnością i relaksem. Przegrody z pleksi, umożliwiające lub nie kontakt wzrokowy z współbiesiadnikami przyjęły różne formy, w zależności od inwencji właścicieli lokalu, fantazji projektanta, nakazu miejscowych władz czy wreszcie konkretnych uwarunkowań kulturowych.

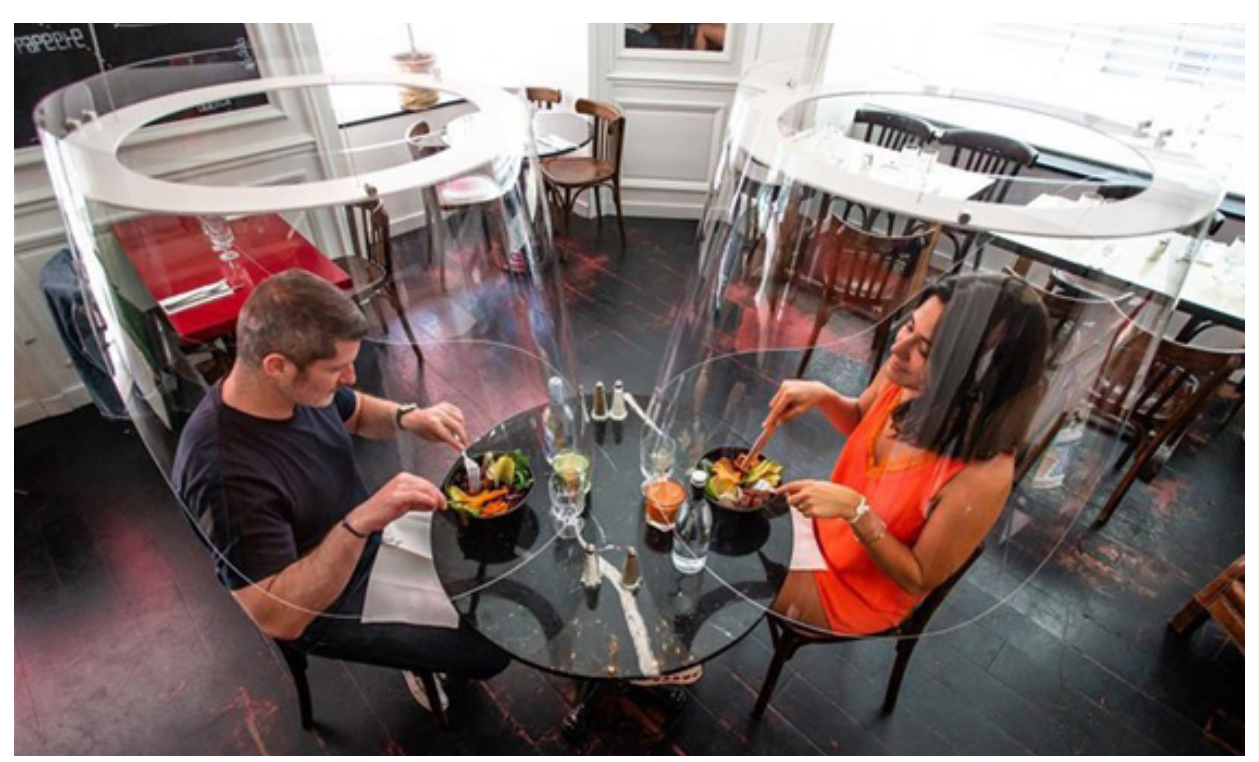

Il. 1. Restauracja w centrum Paryża, 2020

(źródło: https://www.globaltimes.cn/content/1189754.shtml [dostęp: 12.03.2021]). 


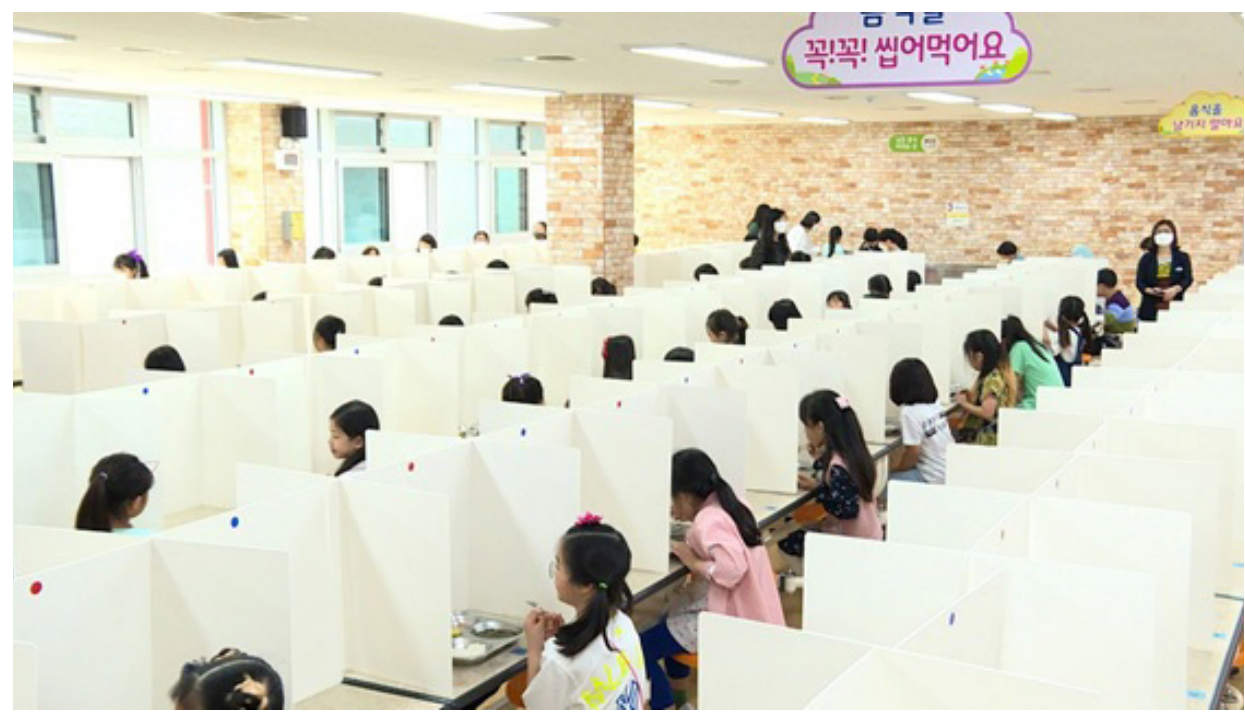

Il. 2. Szkolna stołówka w Seulu, 2020

(źródło: https://www.post-gazette.com/news/world/2020/05/20/South-Korea-high-school-students-return-coronavirus-Korean-schools-reopening/stories/202005200161 [dostęp: 12.03.2021]).

\section{Kult bez wyznawców}

Czy ktoś kiedykolwiek wyobrażał sobie świat bez pielgrzymek do Mekki? Albo drogę krzyżową w Rzymie bez wiernych? Streamingowa kamera skierowana na Al-Kaba pokazywała zwykle niezliczone thumy wirujące wokół relikwiarza świętego kamienia. Było to dla uczestników doświadczenie niezwykłe, kojarzone z bliskością nie tylko boską, ale też ludzką. Ubrane na biało postacie przemierzały ramię w ramię kilometry białej posadzki, aby zbliżyć się na krótką chwilę do hadżaru. Hadż 2020 wyglądał zupełnie inaczej. Przystosowana do przyjmowania ogromnej liczby pielgrzymów przestrzeń wielkiego meczetu wydawała się jeszcze bardziej monumentalna niż zwykle. Po białej posadzce $\mathrm{z}$ wykreślonymi strefami dystansu przesuwały się w dużych odstępach pojedyncze postacie, którym udało się odbyć tę najważniejszą w życiu muzułmanina podróż.

Plac Świętego Piotra, główny plac Watykanu, swój ogromny rozmiar zawdzięcza prognozowanym tłumom wiernych gromadzącym się przed kaplicą. Przestrzeń obrysowana z dwóch stron białym portykiem Berniniego otacza przybywających pielgrzymów, przygarnia ich do siebie. Plac jest miejscem spotkań z papieżem, audiencji generalnej, celem wędrówki turystów z całego świata. Organizowane są tutaj duże kościelne uroczystości, ponieważ ogromny teren może pomieścić do 300 tys. osób. Plac na co dzień rozbrzmiewa gwarem rozmów, rozbłyska fleszami, mieni się kolorami parasolek. W świąteczne dni staje się miejscem wspólnej modlitwy dla tysięcy wiernych. Wielkanoc 2020 zmieniła sposób funkcjonowania tej pięknej przestrzeni. Organizowana w Wielki Piątek tradycyjna droga krzyżowa nie odbyła się jak zwykle w Koloseum, ale na zupełnie pustym placu Świętego Piotra. 
TOM 2 (2021), NR 1

Papieżowi prowadzącemu nabożeństwo towarzyszyło zaledwie kilkanaście osób. Pusta przestrzeń była jedynym uczestnikiem odbywającej się uroczystości.

Ściana Płaczu rzadko bywała tak samotna jak w czasie ostatniego roku. Przed świętem Pesach w 2020 roku ze ściany wyjęto tradycyjnie umieszczane tam karteczki z modlitwami wiernych, a ścianę zdezynfekowano. Ze względu na święto zezwolono wyjątkowo na modlitwy pod ścianą 10-osobowym grupom. Przestrzeń dawnej świątyni jerozolimskiej zamarła w obliczu wszechobecnej pustki.

\section{Wspomnienie 2. Rzym, 2016}

Zwiedzanie w pełnym słońcu nie jest moim ulubionym zajęciem. Dlatego do centrum wybieramy się dopiero po południu. Zachodzące słońce nie dokucza swoim jasnym obliczem, nie widać licznych wycieczek oprowadzanych przez zawodowych pilotów, którzy w końcu też chcą mieć życie rodzinne i wieczory wolą spędzać w domach. Wokół Koloseum jest mało turystów, wejście na schody prowadzące na alejkę wijąca się wokół Forum Romanum jest zupełnie puste. Z pomocą przychodzi jeszcze niespodziewana zmiana pogody i lekka mżawka. Jest uciążliwa na tyle, że prawie wszyscy w zasięgu wzroku rezygnują z dalszego spaceru. Pozostajemy sami wobec ogromu zabytkowej przestrzeni. Nikt nie przeszkadza, nie wchodzi w kadr, miejsce wydaje się zupełnie wyludnione. Jest to niezwykłe doświadczenie w mieście, gdzie prawie nigdy nie można doznać poczucia samotności i dystansu. Opuszczoną przez ludzi przestrzeń można odczuć bardziej i wyraźniej, skupić się na niej, zachwycić się nią.

\section{Muzyka w pustej filharmonii}

Pandemiczny koncert noworoczny w filharmonii wiedeńskiej zapisze się pewnie na zawsze w historii muzyki. Orkiestra na tle ściany kwiatów w uznanej za jedną z najpiękniejszych na świecie sal koncertowych o idealnej akustyce, prowadzona przez światowej sławy dyrygenta Riccardo Mutiego, musiała zmierzyć się z wielkim wyzwaniem. Tradycyjny koncert odbywający się po raz pierwszy bez udziału publiczności żywo reagującej na płynącą ze sceny muzykę mógł być odbierany raczej jak generalna próba podglądana zza kurtyny. Spomiędzy pustych miejsc na widowni Złotej Sali słychać było aplauz nieobecnych ciałem melomanów, którzy za pośrednictwem internetu przesyłali oklaski dla wspaniałych wykonawców. Musikverein ${ }^{13}$ dzięki brakowi zwyczajowego tłumu uczestników wydarzenia mogła pokazać się w pełnej krasie, zaprezentować każdy szczegół swojego bogato dekorowanego wnętrza. Muzyka przyzwyczajona do odbiorców w pustej sali brzmiała jednak nieco inaczej, była bardziej wyobcowana i walczyła z głuchą pustką zalegającą na widowni.

13 Nazywana Złotą Salą (Großer Musikvereinssaal), uznana jest za najlepszą salę koncertową. Co roku odbywa się tutaj oczekiwany przez publiczność tradycyjny koncert noworoczny. Sala mieści 1744 miejsc siedzących oraz 300 miejsc stojących, które do wspomnianego koncertu w roku 2021 zawsze były zajęte. 
TOM 2 (2021), NR 1

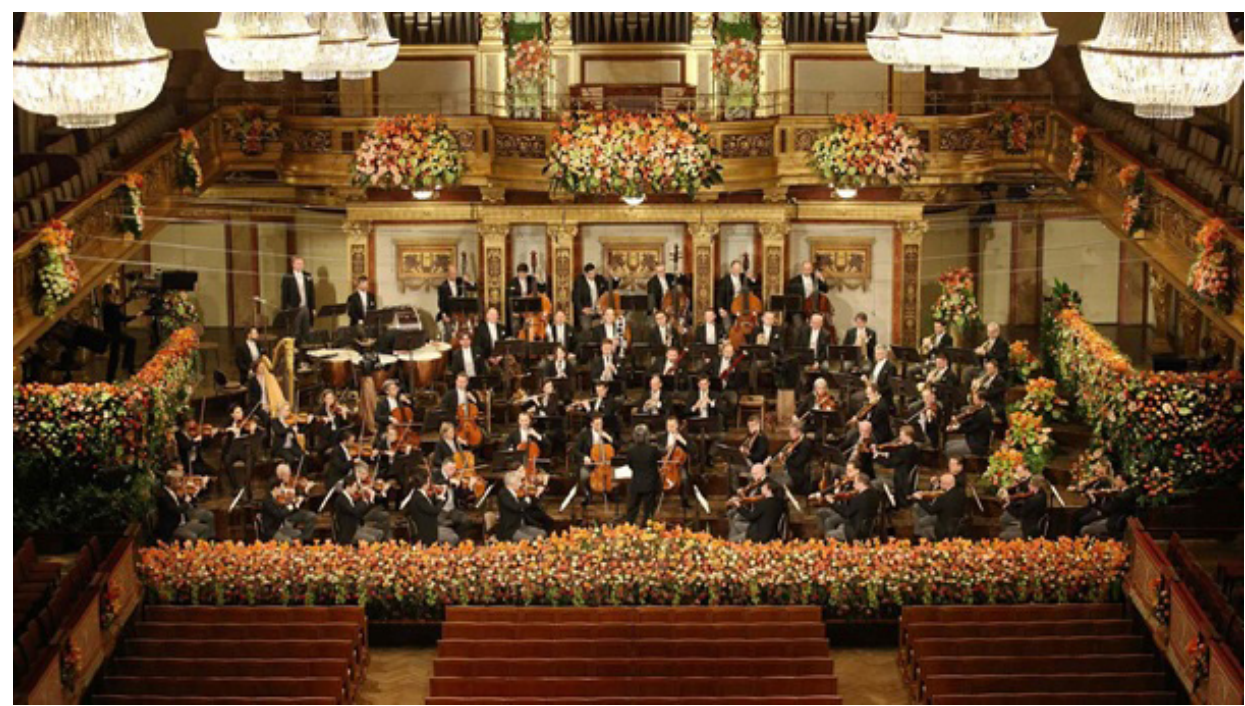

Il. 3. Koncert noworoczny w Wiedniu

(źródło: https://www.wienerphilharmoniker.at/en/press/5ix4ion-8Fn5-R4cvkn8 [dostęp: 12.03.2021]).
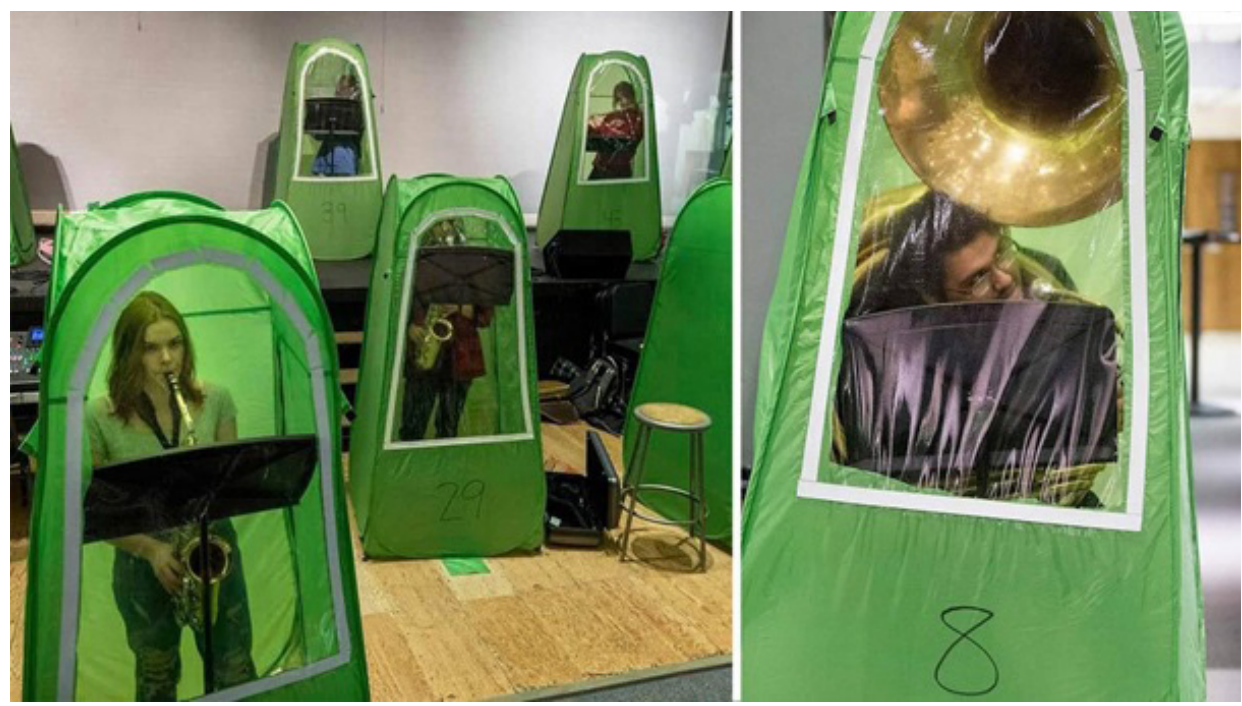

Il. 4. Próba w szkole muzycznej w Waszyngtonie, 2020 (źródło: https://www.classicfm.com/music-news/coronavirus/washington-school-band-pop-up-tents/ [dostęp: 12.03.2021]).

\section{Kamerką w intymność}

Strefa prywatna była do tej pory ostoją i azylem każdego człowieka. Do tej strefy, oprócz najbliższych członków rodziny, miały dostęp jedynie te osoby, które zostały obdarzone szczególnym zaufaniem. Udostępnienie swojej przestrzeni prywatnej było wyborem każdego z nas. Nagła konieczność porozumiewania się za pomocą urządzeń zdalnych zaburzyła tę odwieczną prawidłowość. Dotknęło to najbardziej uczniów, czasem również pracowników, którzy zostali zmuszeni do „,wpuszczenia obcych” w swój intymny świat. Sypialnia, pokój odpoczynku przestały być prywatną oazą, siłą zostały 
TOM 2 (2021), NR 1

upublicznione bez pytania o zgodę ich właścicieli. Przestrzenie najbardziej prywatne zmieniły swoją istotę, przestały spełniać swoje dotychczasowe funkcje. Zamiast otulać swoich mieszkańców spokojnym bezpieczeństwem, stały się miejscem pracy, nauki, a co za tym idzie, często areną osobistych porażek i niepowodzeń. Człowiek został pozbawiony w ten sposób swojej prywatnej przestrzeni ochronnej, która w momentach krytycznych przynosiła zwykle ukojenie i możliwość wyciszenia. Stracił przestrzeń intymną, od zawsze zarezerwowaną jedynie dla jego najskrytszych myśli i poczynań, dającą możliwość zachowania wewnętrznej harmonii.

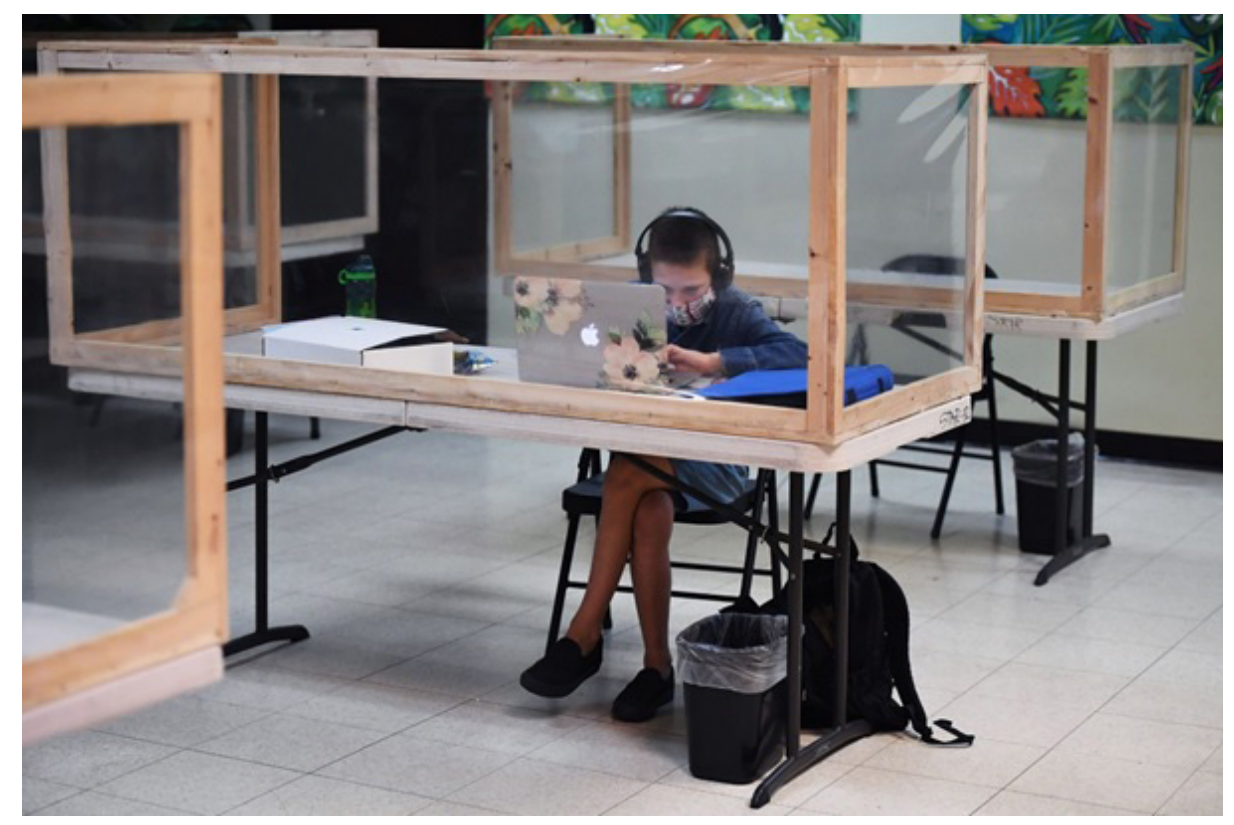

Il. 5. Działająca szkoła w USA - alternatywa dla nauczania online (Photograph: ROBYN BECK/Getty Images, źródło: https://www.wired.com/story/everything-we-know-now-about-schools-kids-and-covid-19/ [dostęp: 12.03.2021]).

\section{Luxury room miejscem odosobnienia}

Pokoje hotelowe, przystosowane i zaprojektowane z myślą o krótkotrwałym w nich pobycie, $\mathrm{w}$ trakcie trwania pandemii w wielu przypadkach zamienione zostały na izolatoria dla zakażonych lub podejrzanych o zakażenie COVID-19. Luksusowe wnętrza z pięknym widokiem rozpościerającym się z okien stały się z dnia na dzień miejscem odosobnienia ${ }^{14}$. Ich lokatorzy zamknięci na co najmniej kilkanaście dni w małej, choć dobrze wyposażonej przestrzeni musieli zmierzyć się z samotnością i niepewnością. Hotel, miejsce związane zwykle z przyjemnością i marzeniami o podróżach, stało się poprzez zmianę podstawowej jego funkcji miejscem swoistej opresji. Sen o przygodzie i podróży zrealizował się w najmniej oczekiwany sposób. Nastąpiło odwrócenie roli miejsca. Zamiast wracać przekraczającej normę prawną lub moralną. Formy izolacji oraz dystansu społecznego opisuje Marek Butrym w artykule Dystans jako sankcja społeczna („,Opuscula Sociologica”, 2012, nr 1). 
TOM 2 (2021), NR 1

do swojego pokoju po dniu pełnym wrażeń, izolowany „skazany” został na samotne pozostawanie w nim przez 24 godziny na dobę. Luksusowa i pożądana dawniej przestrzeń, zmieniając swoją właściwość, stała się dla swego lokatora czymś w rodzaju więzienia.

W sieci zaczęły krążyć liczne ogłoszenia dotyczące mieszkań, apartamentów czy hoteli zapraszających na odbycie w nich przymusowej kwarantanny ${ }^{15}$. Reklamujący prześcigali się w pomysłach na sprzedaż swoich usług. Oferowano panoramiczne widoki na wyludnione miasto, zachęcano do pobytu możliwością wypicia Nespresso na przestronnym balkonie, uspokajano zapewnieniem o profesjonalnej i częstej dezynfekcji i możliwości dostaw zakupów pod drzwi. Pomimo tych obietnic piękne wnętrza straciły jednak swoją najważniejszą cechę - jako miejsca przymusowego zamknięcia przestały spełniać marzenia o luksusie, wolności, przyjemności, relaksie i wspaniałej przygodzie.

\section{Wspomnienie 3. Skyline webcams, kwiecień 2020}

Co najmniej kilkanaście pierwszych nocy lockdownu spędzam przyklejona do monitora. Moim przewodnikiem po nowym świecie są kamery online. Zwiedzam znane miejsca, oglądam je w nieznanej dotąd odsłonie. Pusty Plac Świętego Marka przeraża, po placu Duomo w Mediolanie przejeżdża co kilkanaście minut wóz policji lub ekipa dezynfekująca. Kanałami Wenecji przemykają pojedyncze motorówki, na środku Piazza Navona w Rzymie rozgościła się olbrzymia rybitwa, jedynymi żywymi uczestnikami przestrzeni na Piazza Venezia są żołnierze pełniący wartę przed Vittoriano. Jest tak cicho i pusto, że w swoich głośnikach słyszę plusk wody w fontannie przed Schodami Hiszpańskimi. Wytężam wzrok, aby dla swojego spokoju odnaleźć choć jednego przechodnia. Niestety przez wiele dni i nocy ponawiam tę próbę bez wyczekiwanego skutku.

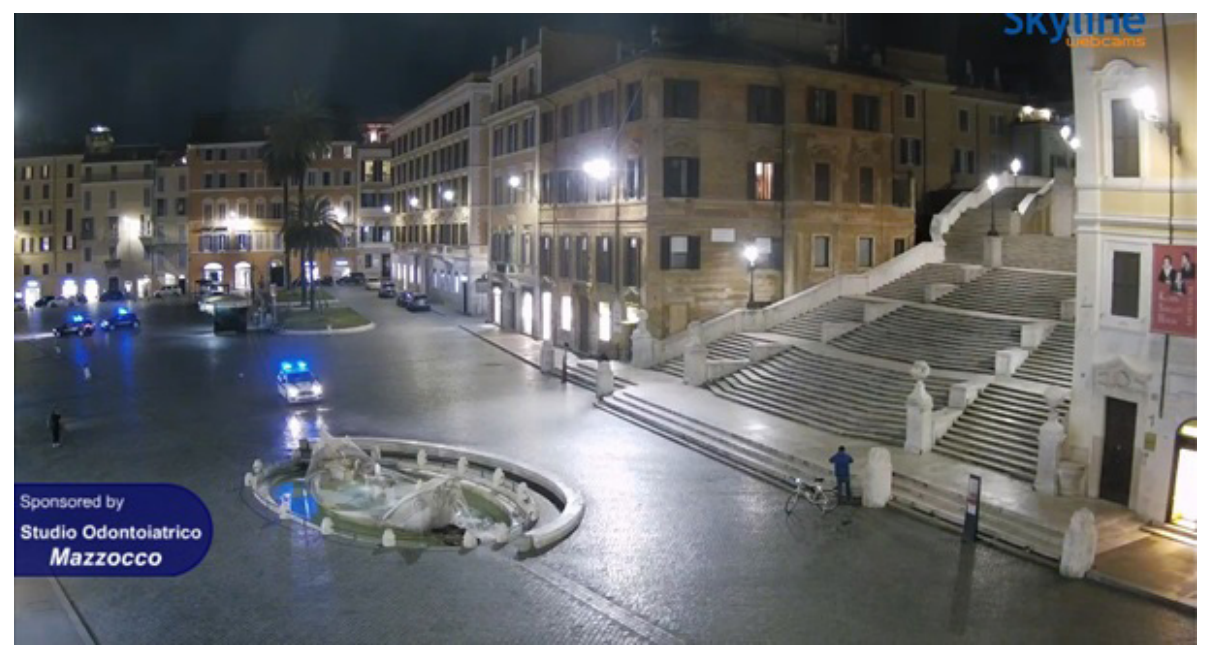

Il. 6. Plac Hiszpański, widok na Schody Hiszpańskie (źródło: https://www.skylinewebcams.com/pl.html).

15 Wpływ kwarantanny na stan zdrowia psychicznego grup izolowanych opisuje Marlena Sokół-Szawłowska („Psychiatria”, t. 18, 2021, nr 1, s. 57-62, www.journals.viamedica.pl/psychiatria). 
TOM 2 (2021), NR 1

\section{Wnioski}

Przestrzeń doby pandemii, stworzona z myślą o korzystających z niej ludziach, stała się samotna, wyobcowana, oderwana od swoich podstawowych, pierwotnych założeń, podobnie jak osamotnieni zostali jej użytkownicy. Tworzona pod kątem użytkowania w określony sposób, projektowana według wymiernych prawideł, podczas przymusowego lockdownu tęskniła za ludźmi, którzy zwykle pozostają jej nierozerwalną częścią. Szkoły, kościoły, place zabaw, restauracje, bary, obiekty sportowe - kryły się puste za zakurzonymi szybami, traciły swój wdzięk, urok i sens istnienia. Miejsca tworzone dla ludzi, pozbawione ich obecności, stały się jedynie pustą dekoracją dla przemijającego obok czasu.

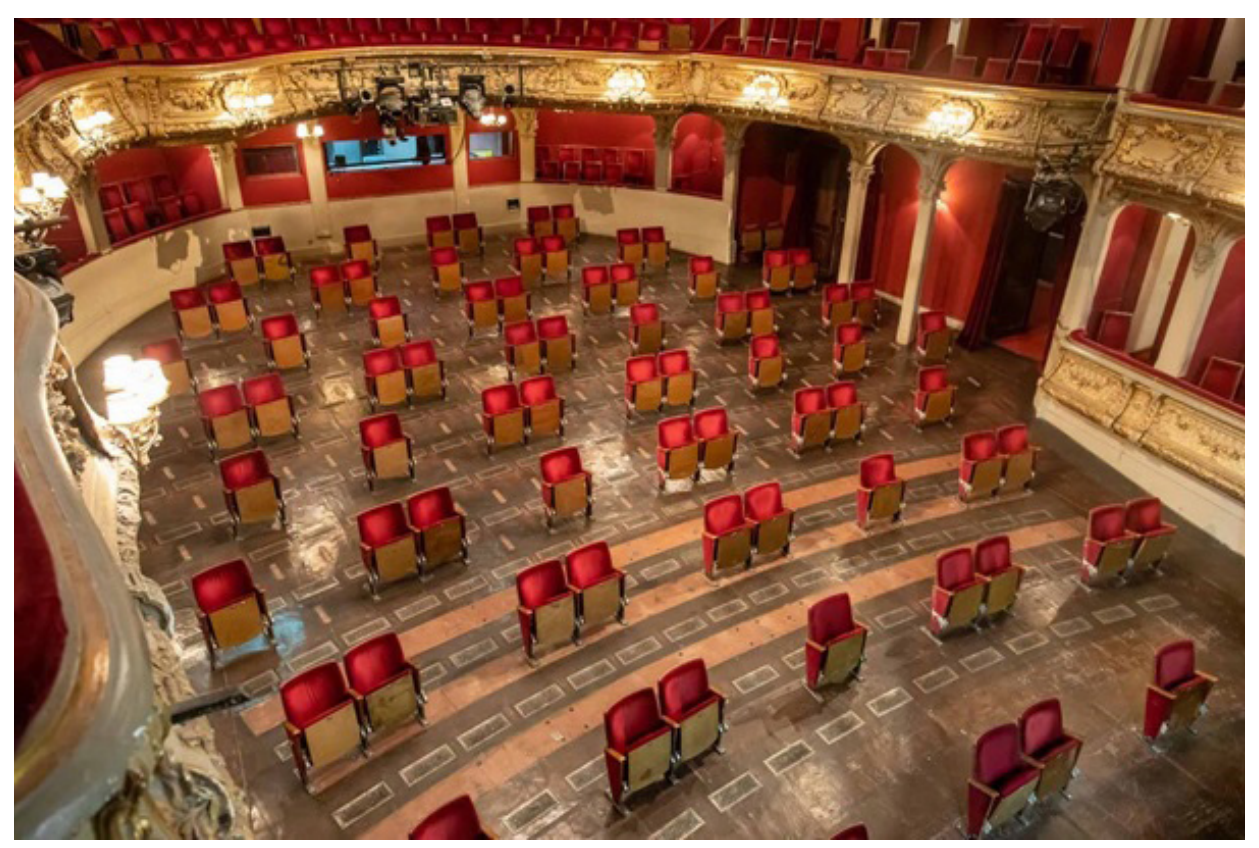

I1. 7. Theater am Schiffbauerdamm w Berlinie, 2020 (Photo by Moritz Haase, źródło: https://www.afar.com/magazine/photos-berliner-ensemble-shows-future-of-socially-distant-theaters [dostęp: 12.03.2021]).

Zastanawiamy się, czy obecna sytuacja jest przejściowa, czy będzie trwała dłużej. Według niektórych naukowców miną miesiące, a według innych może nawet lata, zanim powrócimy do dawnej ,normalności”. Coraz częściej słyszymy jednak głosy, że świat, do którego tak bardzo się przyzwyczailiśmy, już nie powróci. To skłania do zadawania pytań o naszą przyszłość w kontekście organizacji codziennego życia. Jeśli będziemy zmuszeni do całkowitej zmiany naszych przyzwyczajeń, niezbędne będą nowe rozwiązania architektoniczne, projektowe, wzornicze, technologiczne, medyczne i wszelkie inne, związane ze wszystkimi aktywnościami człowieka, które mogą zostać uznane za potencjalnie zagrażające życiu czy zdrowiu. Będziemy potrzebować ogromnej rzeszy specjalistów, którzy przygotują dla nas nową, bezpieczną przestrzeń. Potrzebny jest paradygmat nowej postcovidowej przestrzeni, opisanie jej uwarunkowań, wymogów i konkretnych wytycznych dla niemal każdej dziedziny 
TOM 2 (2021), NR 1

projektowania. Prawdopodobne jest, że przestrzenie i wnętrza publiczne co jakiś czas sprostać będą musiały konieczności wprowadzenia nagłych zmian, szybkiego dostosowania do nowych wymogów i odmiennego sposobu użytkowania. Już w styczniu 2021 roku w ramach Pre-Opening 4 Design Days $2021^{16}$ można było zapoznać się z nowymi kierunkami uwzględniającymi konieczne zmiany w myśleniu o projektowaniu. Zastanawiano się nad możliwością połączenia restrykcyjnych zasad dystansu społecznego z zachowaniem dobrostanu emocjonalnego. Rozważano konieczność zastosowania nowych technologii umożliwiających „,bezdotykowe” korzystanie z przestrzeni. Ponieważ problem pandemii najmocniej zaznaczył się na terenach najgęściej zaludnionych, coraz częściej bada się zastosowanie różnorodnych smart-technologii umożliwiających budowę inteligentnego miasta. Rozważa się zastosowanie dokładnego monitoringu, systemu analizy wizyjnej otwartej i zamkniętej przestrzeni, zastosowania w przestrzeni publicznej materiałów bezpiecznych - szkła odpornego na bakterie i drobnoustroje, farb bakteriobójczych, lamp UV służących do odkażania zamkniętych pomieszczeń. Coraz częściej postuluje się budowę szerszych chodników, umożliwiających utrzymanie zalecanego dystansu oraz tworzenie sieci dróg dla rowerów, będących alternatywą dla transportu publicznego. Cenne stają się parki czy inne otwarte obszary w centrach miast, umożliwiające w czasach lockdownu bezpieczne przebywanie na świeżym powietrzu, czy też małe sklepy otwierane poza popularnymi galeriami handlowymi. Po rocznym zamknięciu większości państw i różnych doświadczeniach epidemiologicznych główny nacisk kładzie się na projektowanie i tworzenie nowych przestrzeni pod kątem umożliwienia zachowania jak największego dystansu, mającego służyć zdrowotnemu bezpieczeństwu społeczeństwa.

Miejmy jednak nadzieję, że spacer po zatłoczonym placu Świętego Marka, kawa wypita w przytulnej kafejce w Paryżu czy bycie częścią kilkutysięcznej widowni na wielkim plenerowym koncercie nie pozostaną jedynie naszymi pięknymi wspomnieniami. 


\section{Bibliografia}

Gehl J., Miasta dla ludzi, Kraków 2018.

Gibała-Kapecka B., Sztuka projektowania (miejsc) przestrzeni międzykulturowych, [w:] Architektura na styku kultur. Nowa Przestrzeń 2018, Kraków 2018.

Hall E.T., Ukryty wymiar, Warszawa 1976.

http://cejsh.icm.edu.pl/cejsh/element/bwmeta1.element.desklight-63fcb3c3-bdfb-4156-bf9b-94343eaa2cb4

[dostęp: 10.03.2021].

https://www.4dd.pl/2021/pl/pre-opening-4-design-days-2/442/ [dostęp: 10.03.2021].

https://www.afar.com/magazine/photos-berliner-ensemble-shows-future-of-socially-distant-theaters [dostęp: 12.03.2021].

https://www.classicfm.com/music-news/coronavirus/washington-school-band-pop-up-tents/ [dostęp:

12.03.2021].

https://www.globaltimes.cn/content/1189754.shtml [dostęp: 12.03.2021].

https://www.post-gazette.com/news/world/2020/05/20/South-Korea-high-school-students-return-coronavirus-Korean-schools-reopening/stories/202005200161 [dostęp: 12.03.2021].

https://www.wienerphilharmoniker.at/en/press/5ix4ion-8Fn5-R4cvkn8 [dostęp: 12.03.2021].

https://www.wired.com/story/everything-we-know-now-about-schools-kids-and-covid-19/ [dostęp: 12.03.2021].

Pallasmaa J., Oczy skóry, Kraków 2012.

Paprzyca K., Miejsce i wspólnota miejsca w strukturze miasta?, ,inAW Journal Multidisciplinary Academic Magazine", 2020.

Skibińska B., Skazani na samotność? O konsekwencjach izolacji spolecznej w wybranych jej kontekstach, „Studia Edukacyjne”, 2017.

Sokół-Szawłowska M., Wpływ kwarantanny na zdrowie psychiczne podczas pandemii COVID-19, „Psychiatria", 2021 (www.journals.viamedica.pl/psychiatria).

Stryszowska-Winiarz K., Wielowymiarowość przestrzeni publicznych, ,inAW Journal Multidisciplinary Academic Magazine", 2020.

Tuan Y.F., Przestrzeń i miejsce, Warszawa 1987.

Wallis A., Socjologia przestrzeni, Warszawa 1990. 
TOM 2 (2021), NR 1

Utwór udostępniany na licencji Creative Commons Uznanie autorstwa 4.0 Międzynarodowe

Artykuł recenzowany

Wydawca: Akademia Sztuk Pięknych im. Jana Matejki w Krakowie, Wydzial Architektury Wnętrz

Redakcja: prof. dr hab. Beata Gibala-Kapecka, dr Joanna Lapińska

Opracowanie graficzne: Joanna Łapińska

Czasopismo „inAW Journal - Multidisciplinary Academic Magazine” powstało dzięki dofinansowaniu w ramach projektu „Projektowanie przyszłości - program rozwoju Akademii im. Jana Matejki w Krakowie na lata 2008-2022” 